\title{
National Arts and Crafts in the Content of Art Education of Russia
}

\author{
Linar G. Akhmetov ${ }^{1}$, Vyacheslav S. Badaev ${ }^{1}$, Valentina A. Komelina ${ }^{2}$ \& Vladimir K. Kuzmin ${ }^{2}$ \\ ${ }^{1}$ Engineering and Technology Faculty, Kazan Federal University, Russia \\ ${ }^{2}$ Engineering and Technology Faculty, Mari State University, Russia \\ Correspondence: Linar G. Akhmetov, Engineering and Technology Faculty, Kazan Federal University, \\ Kazanskaya street 89, Elabuga, 423600, Russia.
}

Received: October 24, 2014 Accepted: December 3, 2014 Online Published: December 18, 2014

doi:10.5539/res.v7n1p1 URL: http://dx.doi.org/10.5539/res.v7n1p1

\begin{abstract}
Main objective of this work is orientation of pedagogical thought to system use of an art material of the Russian national arts and crafts and, as a result, construction on the basis of it flexible educational technologies in the field of visual art at school. In particular, in article is opened value of studying of national arts and crafts in a context of formation of art culture of youth, conditions of integration of an art material of folk art in process of learning of fine art. Also in article are designated approaches in respect of definition of conditions of integration of a plastic and figurative material of folk art in the content of art education at school (national and regional, historical and art criticism and design). There is proved relevance of idea of synthesis of the national and applied and realistic fine arts in educational process. And, at last, is opened educational potential and prospects of folk art in creation of the content of learning in the sphere of art education.
\end{abstract}

Keywords: the formation art culture, artistic traditions, the conditions of the integration of artistic-imagery material of national decorative-applied art in the content of teaching fine arts

\section{Introduction}

It is quite natural that in the present, in deeply progressive searches of the pedagogical thought anxious with definition of means, providing continuity in spiritual and esthetic, cultural and intellectual development of generations, means which besides can have essential impact on efficiency and quality of art education, in the field of close attention there is a peculiar world of traditional national crafts and crafts.

Noting that in products of art handcraft masters it is recorded how the national memory connecting the past with the present and the future, we inevitably arrive at idea that acquaintance to national arts and crafts and development of its art language can and has to have a certain impact on formation of art culture of the person, development of its creative abilities (Rappoport, 1969).

Questions of interaction and synthesis possibility of national arts and crafts and realistic types of the fine arts, having become one of effective and radical tendencies in art education, stimulate creative search of many scientists-theorists of art (Arnkheym, 1974). Deep regularity is expressed that the modern content of learning the fine art gradually concentrates and reinterprets a huge material of national art heritage (Shpikalova, 1979).

Not incidentally ideas of use of educational and creative potential of folk art find reflection in many scientific pedagogical researches of the last decades, not to mention interesting, extensive and representative discussions on problems of integration of arts and crafts in the content of the art education, not stopping up to the present moment in the sphere of art pedagogics. As can be understood, national arts and crafts-not so frictionless area of pedagogical activity. The problem of synthesis of national arts and crafts and realistic types of the fine arts in the course of art education therefore is so actual, that is connected with big and sometimes quite critical problem of the present. Questions of preparation of socially adequate and tolerant younger generation. Understanding of this problem is carried out by difficult, and sometimes inconsistent ways.

At first sight seems obvious that the common purpose of folk art and system of art education is formation of harmoniously developed person. However nowadays it must be acknowledged some extent a strange situation. Despite lack of deficiency of ideas, concepts, approaches to conditions of integration of the richest material of folk art in the content of the art education, insufficiently researched area is a definition of optimum conditions of its inclusion in real educational process and in regular school, and in secondary spezialized schools, and in 
university. At some wins of teachers-experimenters of the complete program of art education "Art figurative language of national arts and crafts + Learning of a method of the realistic fine arts = Formation of art culture and development of creative abilities of youth" still isn't created.

\section{Results and Discussions}

Before we will approach to clearing of possibility of creation of such program, we will try to define, what involves the modern artists-teachers, traditional, "primitive" area of national arts and crafts. And in this regard more specifically to understand the main prerequisites, regularities and conditions of optimization of inclusion of national arts and crafts in the content of art education at school in a context of formation of art culture of pupils.

Features of creativity were fixed in arts and crafts at each nation in the form of complete systems of art traditions. The continuity of traditions allowed to fulfill a perfect functional form of household items, character and a measure of their decorative decoration. Thus for the solution of the creative problems, masters found exact, extraordinary laconic and figurative means. Tradition in folk art-result of difficult process of art understanding and learning of reality, a real exponent of formation of figurative thinking of the folk.

The art tradition is substantial. It is necessary to comprehend this pithiness as a matter of experience the present. Modernity - continuation of life of tradition. Studying of national arts and crafts in a context of formation of art culture of youth is, first of all, solving of a problem of relationship of traditions and modernity-dialogue of folk and realistic art by definition of conditions of integration of an art material of folk art in process of training in the fine arts.

Dialogueness of realistic and national arts and crafts is one of the main conditions of self-development of culture and its most intrinsic characteristic when one sense, one system of values "opens the depths", having met and having adjoined to other sense, other values. It assumes integration of a material of folk art into real educational process, development of plastic figurative language of art crafts of Russia, acts as a necessary and organic link between the realistic fine arts and national arts and crafts, allowing to form purposefully and effectively art culture of younger generation.

As a whole, in respect of definition of conditions of integration of a plastic and figurative material of folk art in the content of art education at schools it is possible to allocate two most pronounced approaches:

a) National and regional approach at which prevails illumination of questions of history of formation and development of national art crafts and is considered quite sufficient to be limited to studying of technique and the production technology of handicrafts, elements of decoration of products, learning of traditional methods and ways of art processing of natural and industrial materials. The similar treatment of the principles of selection and inclusion of various forms and types of folk art in the content of art education can be met in scientific researches of the vast majority of representatives of the former federal republics of the Soviet Union, and also - the Russian Caucasus and Transcaucasia.

b) Historical and art criticism and design approaches, when ethical and esthetic aspects of learning of children dominate, by means of folk art. The attention of pupils is focused generally on informative, semantic, estimative, communicative, educational, utilitarian functions of arts and crafts. The main and defining aspect of art education is considered valuable socializing, world outlook, connected with formation of historical and cultural memory. Thus art and creative development of youth fades into the background and is treated often only as means of strengthening of so-called "main types" of education, than unfairly overshadowed the development of theory and practice of fine art language.

The design direction of formation of art culture of younger generation by means of the fine arts are in many respects a basis for lesson plans of B. M. Nemensky, B.P.Yusova, T.Y. Shpikalova etc.

Thus dominating idea of this study aids is direct export of esthetic values, cultural samples, norms, technologies of arts and crafts to the content of art education (Lerner, 1981). Clearly, exactly from here results to a certain extent subjectivity, one-sidedness, and as a whole, arbitrariness in treatment of a role and place of national arts and crafts in the content of art education of youth. And, as self-evident, it is considered that any kind of folk art, being included in the content of art education, sometimes regardless of age and preferences of pupils, has positive impact on creative formation of the child.

National and regional approach to integration of an art material of national arts and crafts into educational process of regular school initially and by definition has especially local character and contradicts:

with the principles of generality and availability of education because of the closest communication with history, national and religious traditions and conditions of a life of indigenous people. The main factor here is that 
outside concrete ethnic community, at other people, due features of their own historical way of development, is quite enough the traditional and deeply original forms of arts and crafts;

with the declared principle of preparation for society of harmoniously developed personality. The prospect of formation of ability of the objective emotional and valuable relation of the person to art of the past and realities of the modern world through art in its most various display, and also understanding of art and esthetic characteristics of works of art of the people in a context of cultural life of mankind on a material of the limited by national framework arts and crafts creativity it is represented more than problematic. Here it is necessary to take into account that, at all positive moments of such decision, the national and regional component inherently is focused on the maximum understanding and the consideration of specifics of that culture which becomes object of design activity;

with possibility of coordination of the educational purposes and problems of learning of a concrete art material of national arts and crafts with the purposes and problems of learning in the fine arts as a whole. In this case is ignored the problem of elimination of delimitation in setting of educational and creative purposes and tasks-a problem of parallelism of functioning in borders of one subject of two art systems, two art worlds having the general nature of an origin - realistic and national arts and crafts types of the fine arts.

Restrictions, which impose the above contradictions on process of learning the fine arts at school, allow to speak about opportunity to some extent high-quality assimilation by the child only fragmentary, highly specialized-non-system knowledge and concepts of laws, rules, receptions and ways of the practical decision rather technological, than creative tasks within one, two types of arts and crafts.

As can be seen, the generalized analysis of concepts of inclusion of an art material of traditional creativity in process of the fine arts learning, and acquaintance to practice of realization of theoretical ideas in concrete guidance paper testify about paradoxical, at first sight situation. The paradox is that an art material of national arts and crafts heritage, allowing to solve successfully private problems of mastering any concrete type of folk art, as a whole, owing to non-system approach to inclusion it in real educational process, is insufficiently rationally and effectively used in the field of formation of art culture of youth (Dewberry, 2011).

On the basis of the above we inevitably come to a conclusion that the idea of synthesis of the folk arts and crafts and realistic fine arts within common educational process didn't lose the relevance so far (Johnson, 1995; Joselit, 2012). The solution seems that for full formation of art culture of youth and development of specific abilities to the fine arts is necessary:

To isolate and select on the basis of the analysis of specifics of art figurative language various national crafts of Russia those their types and forms, which would be system, key for understanding and learning both arts and crafts creativity of the native culture, and folk art of other nationalities;

To define the educational and creative activity uniting functioning of national arts and crafts and realistic types of the fine arts within common process of learning. Allowing, besides, active use of the art experience found at lessons of drawing and painting from nature, in the course of stylization of realistic portrayal of natural forms in decorative in a context of a studied type of folk art.

To define optimum didactic composition of the isolated types of national arts and crafts in the content of the art education, demanded for development of basic abilities of a full-fledged embodiment of an artistic image and in system of traditions of different types of art crafts of Russia and in the realistic fine arts.

To develop, theoretically to prove and experimentally to check the methodical program of system realization of educational and creative potential of national arts and crafts in the course of learning in the fine arts at school.

In the reasonings we recognize that dialogue of realistic and national arts and crafts has to overcome isolation and one-sidedness of the positions of everyone, finding new opportunities and prospects of formation and development of art culture of youth. Existing in isolation or entering the conflict with each other, each of these cultures is doomed to the solution of the internal art problems - one owing to conservatism of values and institutes, domination of a vector of preservation, another-because of ignoring of traditional, basic cultural values, norms, technologies.

These two independent, many-sided, various and at the same time genetically related art systems quite can and have to form the complete content of art education and esthetic education. Esthetic education at lessons of the fine arts, on a basis and in the course of which is carried out formation of spiritual culture of pupils, has to include folk art and professional art as the most important components of joint process providing harmonious development of the personality. It, in turn is an essential condition of success of revival of national culture, further development of traditions of folk art (Kuzin, 1982). 


\section{Conclusions}

Knowledge of folk art is the way which has been historically checked in system of an apprenticeship, existing and until now in national art crafts. The art means of expression peculiar to folk art-active identification of a material, special expressivity in the line and color, high culture of the rhythmic organization of the image-are quite actual, demanded for expression of emotional experiences, esthetic preferences and aspirations in the present (Turner, 2006). By the opportunities, richness of a graphic material, originality of a plastic rhythm of vision, the folk art possesses huge educational and creative and educational potential and is extremely perspective at the corresponding creation of the content of learning in the sphere of art education.

\section{References}

Arnkheym, R. (1974). Art and visual perception. Moscow: Progress.

Dewberry, D. (2011). Dewberry's Big Book of Decorative Painting. A Complete Guide to One-Stroke Tips and Techniques by Donna Dewberry. Retrieved from http://www.betterworldbooks.com /donna-dewberry-s-big-book-of-decorative-painting-a-complete-guide-to-one-stroke-tips-and-techniques

Johnson, E. H. (1995). Modern Art and the Object: A Century of Changing Attitudes (Revised). Icon Editions. New York.

Joselit, D. (2012). After Art. Princeton University Press. Princeton, NJ.

Kuzin, V. S. (1982). Psychology / Under the editorship of B. F. Lomov. Moscow: Higher school.

Lerner, I. Y. (1981). Didactic bases of methods of teaching. Moscow: Pedagogics.

Rappoport, S. C. (1969). Thinking in images and decorative effect. Artistic image and decorative effect in art of Asia and Africa. Moscow: Science.

Shpikalova, T. Y. (1979). Folk art at lessons of decorative drawing. Moscow: Prosveschenie.

Turner, M. (2006). The Artful Mind: Cognitive Science and the Riddle of Human Creativity. Oxford University Press. New York. http://dx.doi.org/10.1093/acprof:oso/9780195306361.001.0001

\section{Copyrights}

Copyright for this article is retained by the author(s), with first publication rights granted to the journal.

This is an open-access article distributed under the terms and conditions of the Creative Commons Attribution license (http://creativecommons.org/licenses/by/3.0/). 